\title{
EFEKTIVITAS PERMAINAN KARTU KUARTET DAN METODE MENGHAFAL
}

\author{
Hasnianti \\ Pascasarjana UIN Alauddin Makassar \\ Jl. H. M. Yasin Limpo No. 36 Romangpolong, Somba Opu \\ Kab. Gowa, Sulawesi Selatan 92113 \\ e-mail: asnipba@gmail.com
}

\begin{abstract}
This study aims to compare the effectiveness of quartet card games and memorization methods for students' mastery of vocabularies. In this study, using quasi quantitative experiments. The sample of this study was purposive sampling taken from class VII A and B as many as 40 students with a population of 150 people. Then the data collection technique used by researchers is the evaluation test relating to the mastery of the consensus existing on the quartet card. The T-test is a formula that researchers use in obtaining research results. Obtained that the experimental class in this case class VII A, amounting to 19 students after treatment, then given a test obtained an average value of 5.8, while the control class, in this case, Class VII B students were 21 students after memorizing the vocabularies method. The same as the consensus in the quartet card and then given a test obtained an average value of 3,6, so it can be concluded that $\mathrm{Ho}$ is rejected and $\mathrm{Ha}$ is accepted because $t$ arithmetic 4,23 is more significant than t table 1,68959.
\end{abstract}

Keywords: Effectiveness; Quartet Card; Memorization Method; Mastery of Mufradat; Arabic.

\begin{abstract}
Abstrak
Penelitian ini bertujuan untuk membandingkan keefektifan permainan kartu kuartet dan metode menghafal terhadap penguasaan mufrodat siswa. Dalam penelitian ini menggunakan kuantitatif quasi eksperimen. Sampel penelitian ini adalah purposive sampling yang diambil dari siswa kelas VII A dan B sebanyak 40 siswa dengan populasi 150 orang. Kemudian teknik pengumpulan data yang dilakukan peneliti yaitu tes evaluasi yang berkaitan dengan penguasaan mufradat yang ada pada kartu kuartet tersebut. Uji $t$ merupakan rumus yang peneliti gunakan dalam memperoleh hasil penelitian. Diperoleh bahwa Kelas eksperimen dalam hal ini kelas VII A yang berjumlah 19 siswa setelah dilakukan perlakuan yang kemudian diberikan tes diperoleh nilai rata-rata 5,8 sedangkan kelas kontrol dalam hal ini siswa Kelas VII B yang sebanyak
\end{abstract}


21 siswa setelah dilakukan metode menghafal dengan mufradat yang sama dengan mufradat yang ada dalam kartu kuartet kemudian diberikan tes diperoleh nilai rata-rata 3,6 sehingga dapat disimpulkan bahwa Ho ditolak dan Ha diterima, karena $t$ hitung hitung 4,23 lebih besar dari $t$ tabel 1,68959.

Kata Kunci: Efektivitas; Kartu Kuartet; Metode Menghafal; Penguasaan Mufradat; Bahasa Arab.

\section{A. Pendahuluan}

Hubungan sosial tidak akan berjalan dengan baik tanpa menggunakan bahasa dengan baik. Kemampuan berbahasa seorang anak berawal dari mendengarkan perkataan orang sekitar terutama kedua orang tua dan keluarganya. Mengikuti menjadi tahap berikutnya setelah terbiasa mendengarkan. Terbiasa mendengar kata "mama" si anak mulai mengikuti dengan pelan "ma ma". Begitu seterusnya mendengar dan mengikuti hingga si anak dapat berbahasa dengan lancar. Menyampaikan dan memahami gagasan, pikiran, dan pendapat memerlukan suatu media yang disebut Bahasa. ${ }^{1}$

Belajar Bahasa Ibu (bahasa sendiri) tidak seperti belajar bahasa Arab (Asing). Bahasa ibu akan didengar setiap harinya sehingga dalam kurung waktu sekitar satu tahun anak akan mulai fasih berbahasa. Berbeda dengan belajar bahasa Arab, karena kondisinya sebagai bahasa asing tentu jarang orang Indonesia menggunakannya dalam kesehariannya. Selain itu, karena bahasa Arab bahasa asing dalam mempelajarinya tidak cukup hanya punya mufradat. Tapi, tidak bisa lepas dari aturan-aturan (kaidah-kaidah) terkait bagaimana menyusun mufradat tersebut menjadi satu kalimat. Penguasaan mufradat tanpa mengetahui aturannya maka sulit untuk berbahasa yang fasih. Tapi mengetahui aturan tanpa mufradat tidak bisa berbahasa. Oleh karena itu, penguasaan terhadap mufradat sangat menunjang keterampilan berbahasa.

Dewasa ini era globalisasi terus merajalela dan tak terelakan menjadikan batas geografis dan budaya menjadi samar dalam pikiran individu karena semua menjadi satu. Mengerti budaya dan bahasa negara di luar Indonesia menjadi penting. sehingga banyak sekolah menambahkan suatu mata pelajaran bahasa asing dalam kurikulum.

\footnotetext{
${ }^{1}$ Khaidir Anwar, Beberapa Aspek Sosio-Kultural Masalah Bahasa (Yogyakarta: Gama Media, 2000), h. 34.
} 
Bahasa Arab misalnya menjadi mata pelajaran tambahan mulai dari sekolah menengah pertama selama berada di bawah naungan Kementrian Agama. Bahasa Arab adalah bahasa asing dan memiliki kesulitan tersendiri dipelajari siswa. Siswa Pesantren lebih terlihat kemampuan berbahasa Asingnya (Arab) karena di Pesantren memiliki metode tersendiri yang didukung oleh kondisi siswanya tinggal di Asrama. Berbeda siswa yang di sekolah umum seperti Madrasah Tsanawiyah dan Madrasah Aliyah apalagi sekolah umum belajar bahasa Asing (Arab) hanya $2 \times 45$ menit per minggunya, tentu ini menjadi sulit bagi mereka.

Pemilihan metode dalam proses pembelajaran penting adanya. Namun bukan berarti penentuan atau penyusunan materi tidak penting. Metode dan materi dalam proses pembelajaran merupakan dua hal yang tidak boleh diabaikan demi tercapainya apa yang menjadi tujuan pembelajaran yang ditentukan dalam RPP (Rancangan Perencanaan Pembelajaran).

Penyusunan Rancangan Perencanaan Pembelajaran (RPP) pada proses pembelajarannya terbagi atas tiga kegiatan yaitu kegiatan pembuka, kegiatan inti dan kegiatan penutup. Kartu kuartet posisinya dalam proses pembelajaran ada pada kegiatan pembuka. Siswa tanpa sadar bermain tapi memperoleh mufrodat.

Terdapat berbagai strategi dalam penyampaian materi tentang kosakata bahasa Arab oleh guru kepada para siswanya. Strategi yang paling ideal yaitu dengan isyarat ataupun tanda yang dimaksud secara langsung. Tujuan dari strategi pembelajaran kosakata ini membatu siswa untuk menerjemahkan bentuk-bentuk kosakata dan mampu menggunakannya dalam bentuk jumlah (kalimat) dengan tepat. Dalam arti yang luas siswa tidak hanya dituntut untuk menghafal kosakata tanpa mengetahui penggunaan dan fungsinya dalam komunikasi. Namun tujuan akhir dari strategi pembelajaran kosakata bahasa Arab ini siswa diajarkan untuk menggunakannya baik dalam bentuk ucapan maupun tulisan. ${ }^{2}$

Berdasarkan hasil penelitian Haris dan Hasan bahwa media kartu bergambar kurang berpengaruh dalam meningkatkan penguasaan kosakata bahasa Arab. Untuk dapat meningkatkan penguasaan siswa terhadap kosakata bahasa Arab perlu menggunakan media yang cocok dan kreatif. Media

\footnotetext{
${ }^{2}$ Abdurochman Abdurochman, "Strategi Pembelajaran Kosakata Bahasa Arab bagi Non Arab," An Nabighoh Jurnal Pendidikan dan Pembelajaran Bahasa Arab 19, no. 1 (2017): 63, https://doi.org/10.32332/an-nabighoh.v19i1.758.
} 
flashcard merupakan salah satu media kreatif yang dapat digunakan untuk meningkatkan daya tangkap siswa dalam menguasai kosakata. Respon atau minat siswa terhadap bidang studi bahasa Arab bisa dirangsang dengan beberapa metode dan media pembelajaran yang menarik dan efisien, salah satunya bisa dengan menggunakan media flashcard. ${ }^{3}$

Sedangkan metode menghafal merupakan metode klasik dalam menambah perbendaharaan kosakata, metode ini dirasa membosankan dan membutuhkan waktu yang banyak. Seiring perkembangan zaman ilmu pendidikan juga demikian berkembang banyak kemudian metode-metode yang sifatnya fun yang diciptakan pegiat ilmu entah mereka yang bergelut di dunia pendidikan formal maupun informal seperti perkampungan dalam pembelajaran berbahasa. Metode menghafal merupakan salah satu metode konvensional yang sudah ada sejak dulu sehingga pengajar dan pegiat bahasa mencoba menciptakan inovasi baru dalam menghafal mufradat. Permainan kartu kuartet merupakan salah satu inovasi baru yang diciptakan dalam menghafal mufradat. Permainan kartu kuartet ini sendiri bukan suatu yang asing bagi kita kelahiran tahun 90 -an. Permainan ini sudah kita mainkan semasa kecil tapi pada saat itu murni hanya untuk hiburan belum terdapat unsur education di dalamnya.

Sejauh ini ternyata permainan kartu kuartet ini tidak hanya digunakan dalam menghafal mufradat bahasa baik itu bahasa inggris maupun bahasa Arab dan lainnya. Tapi, ternyata juga banyak digunakan oleh pengajar mata pelajaran lainnya seperti matematika, pendidikan kewarganegaraan, fisika dan lain-lain. Berangkat dari kenyataan dan melihat fisik kartu kuartet itu sendiri yang di dalamnya terdapat 40 mufradat dan jika dimainkan bisa selesai dalam 10 menit bisa lebih efektif dengan metode menghafal yang jelas-jelas menghafal tapi memang metode ini sudah klasik. Kehadiran permainan kartu kuartet yang lebih inovasi kemungkinan besar meningkatkan motivasi siswa, tapi dalam penguasaan mufradat metode menghafal masih lebih efektif. Pandangan-pandangan peneliti tersebut mengantarkannya untuk meneliti mana lebih efektif antara permainan kartu kuartet dan metode menghafal

\footnotetext{
${ }^{3}$ Muh Haris Zubaidillah dan Hasan Hasan, "Pengaruh Media Kartu Bergambar (Flash Card) Terhadap Penguasaan Kosakata Bahasa Arab," Al Mi'yar: Jurnal Ilmiah Pembelajaran Bahasa Arab dan Kebahasaaraban 2, no. 1 (2019), https://doi.org/10.35931/am.v2i1.90.
} 
terhadap penguasaan mufradat jika dalam penerapan kedua metode tersebut terjadi dalam alokasi waktu yang sama, dan jumlah mufradat yang sama.

Metode permainan ini diuji coba peneliti di sebuah sekolah. Penelitian ini merupakan penelitian eksperimen sehingga dalam penentuan lokasi penelitian tidak terikat, selama penelitian dengan jenis eksperimen bisa dilaksanakan. Madrasah Tsanawiyah Negeri (MTsN) 2 Bone menjadi pilihan peneliti karena melihat di sekolah tersebut siswanya cukup banyak sehingga memungkinkan penelitian ini dilaksanakan di sana.

\section{B. Metode Penelitian}

Pendekatan yang digunakan pendekatan kuantitatif atau analisis data statistik. Bentuk penelitian ini adalah penelitian eksperimen dengan desain penelitian eksperimen semu (quasi experiment) dengan bentuk desain nonequivalent control group design. Quasi eksperimental ini mempunyai ciri utama yaitu sampel yang digunakan untuk kelompok eksperimen maupun sebagai kelompok kontrol diambil secara purposive sampling dari populasi tertentu. ${ }^{4}$ Jenis ini berangkat dari keadaan sampel yang homogen, guru, mata pelajaran dan keadaan sampel yang sama. Gambaran sederhananya terdapat dua grup yang dipilih secara purposive sampling yaitu kelompok eksperimen dan kelompok kontrol. Kemudian kedua kelompok tersebut diberi perlakuan yang berbeda setelah itu diberikan tes hasil tes tersebutlah yang akan dianalisis untuk menjawab rumusan masalah penelitian.

Populasi penelitian ini yaitu semua siswa kelas satu MTs N 2 Bone yang berjumlah 167 yang dibagi menjadi enam kelas. Populasi jenis ini disebut (definite) yaitu objek penelitian yang dapat dihitung atau populasi terbatas. ${ }^{5}$ Siswa menjadi sasaran utama penelitian ini, dimana siswa merupakan sesuatu yang dapat dihitung. Berdasarkan desain penelitian dan berbagai pertimbangan keadaan kelas, guru pengajar, serta karakteristik dan latar belakang murid yang hampir sama maka dipilihlah dua kelas yang merupakan sebagian dari populasi. Sampel tersebut yaitu kelas 7 A sebagai kelas eksperimen dan kelas 7 B dijadikan sebagai kelas kontrol. Jumlah siswa kedua kelas tersebut 40 dari 167 siswa. Teknik ini merupakan purposive sampling yang dilaksanakan sesuai dengan penilaian subjektif peneliti berdasarkan

\footnotetext{
${ }^{4}$ Suharsimi Arikunto, Manajemen Penelitian (Jakarta: Rineka Cipta, 2009), h. 207.

${ }^{5}$ A. Muri Yusuf, Metode Penelitian Kuantitatif, Kualitatif \& Penelitian Gabungan (Jakarta: Kencana, 2014), h. 161.
} 
pengamatan yang telah dilakukan pada pengetahuan calon informan atau responden untuk menjawab pertanyaan penelitian.

Metode pengumpulan data dalam penelitian ini yaitu dengan terjun langsung ke lapangan atau lokasi penelitian untuk mencatat beberapa hal yang dibutuhkan dengan memakai beberapa teknik. Teknik pengumpulan yang digunakan dalam penelitian ini dokumentasi dan tes hasil pembelajaran yang bersifat objektif. Tes yang diberikan adalah tes objektif, setiap pertanyaan disediakan alternatif jawaban yang dapat dipilih dan menghasilkan skor yang konstan. Jika jawaban benar diberi skor 1 (satu) dan jika salah diberi skor 0 (nol). Penelitian ini menggunakan teknik dokumentasi untuk mendapatkan data yang bersifat sekunder berupa daftar nama, jumlah siswa dan profil Madrasah Tsanawiyah Negeri (MTs N) 2 Bone sebagai lokasi penelitian

Salah satu cara untuk mengetahui apakah dua kelompok sampel mempunyai perbedaan rata-rata secara signifikan atau tidaknya adalah uji independent sample t-test. ${ }^{6}$ Ada beberapa metode untuk menghitungnya tapi pada penelitian ini penulis akan memberi dua cara saja, yaitu dengan cara manual dan SPSS 20.

\section{Hasil dan Pembahasan}

\section{Permainan Kartu Kuartet}

Perkembangan anak pada awalnya belum dikaitkan dengan kegiatan bermain. Hal tersebut dikarenakan oleh kurangnya perhatian para ahli psikologi serta terbatasnya pengetahuan pada perkembangan anak. Plato merupakan orang pertama yang menyadari bahwa adanya nilai praktis dalam proses bermain sehingga penting adanya pada dunia anak. Beberapa pendapat lainnya muncul setelah itu yaitu Aristoteles berpendapat bahwa dari kegiatan bermain anak menemukan cita-cita yang akan ditekuni hingga dewasa nantinya. ${ }^{7}$

Menurut Plato metode permainan game, permainan peran (role playing), atau simulasi dan permainan (simulation and game) merupakan salah satu metode pendidikan yang terbaik pada tingkatan dasar. Hal tersebut terlihat dalam ungkapan Plato: "Dalam mendidik anak-anak,

\footnotetext{
${ }^{6}$ Aris Dianto, "Uji Independent Sample T-Test Secara Manual," Aksiomatik, diakses 10 April 2019, https://aksiomatik.wordpress.com/2016/09/08/uji-independent-sample-ttest-secara-manual/.

${ }^{7}$ Mayke S. Tedjasaputra, Bermain, Mainan dan Permainan (Jakarta: Grasindo, 2001), h. 2.
} 
didiklah mereka dengan semacam permainan". ${ }^{8}$ Dari situ terlihat bahwa Plato tak hanya berpikir idealis namun juga praktis.

Menurut KBBI (Kamus Besar Bahasa Indonesia), yang dimaksud kartu yaitu kertas yang hampir sama dengan karcis dengan kertas tebal persegi panjang yang dipergunakan untuk berbagai kebutuhan. ${ }^{9}$ Sedangkan kuartet yaitu kelompok, kumpulan, dan lain sebagainya yang terdiri dari delapan kategori dimana setiap kategori terdiri dari empat kartu. Kartu kuartet merupakan semacam permainan yang terdiri dari beberapa jumlah kartu bergambar, biasanya judul diletakkan paling atas pada kartu dan tulisannya dibold dan ditebalkan, masing-masing dari kartu itu tercantum keterangan berbentuk tulisan yang menjelaskan gambar tersebut dan tulisan gambar dituliskan empat atau dua baris secara vertikal yang berada di tengah-tengah antara gambar dan judul. Tulisan yang menjelaskan gambar itu biasanya dituliskan dengan tinta yang berwarna-warni. ${ }^{10}$

Sebagai kesimpulan dari beberapa pendapat tersebut, kartu kuartet merupakan jenis permainan kartu yang berjumlah 32 kartu dalam satu paknya disertai penjelasan berupa tulisan untuk menjelaskan gambar pada kartu itu.

\section{Metode Menghafal}

Menurut KBBI (Kamus Besar Bahasa Indonesia) metode merupakan "cara yang tersusun dan teratur, untuk mencapai tujuan, khususnya dalam hal ilmu pengetahuan". ${ }^{11}$ Sedangkan metode menurut Muhammad Zein yaitu cara kerja yang umum dan sistematis, misalnya bagaimana ilmu pengetahuan bekerja dan termasuk jawaban dari pertanyaan "bagaimana". ${ }^{12}$ Adapun metode berdasarkan pendapat Saiful

\footnotetext{
8 J. H. Rapar, Filsafat Politik Plato (Jakarta: Rajawali Pers, 1996), h. 118.

${ }^{9}$ Tim Penyusun Kamus Pusat Bahasa, Kamus Besar Bahasa Indonesia, Cet. XVI (Jakarta: Pusat Bahasa, 2008), h. 644.

${ }^{10}$ Indah Setiyorini, "Penggunaan Media Permainan Kartu Kuartet Pada Mata Pelajaran IPS Untuk Peningkatan Hasil Belajar Siswa Di Sekolah Dasar," Jurnal Penelitian Pendidikan Guru Sekolah Dasar 1, no. 2 (2013): 10.

${ }^{11}$ Tim Penyusun Kamus Pusat Bahasa, Kamus Besar Bahasa Indonesia, h. 952.

${ }_{12}$ Muhammad Zein, Metodologi Pengajaran Agama (Yogyakarta: AK Group, 1995), h. 167.
} 
Bahri Djamarah yaitu langkah yang dilakukan untuk mencapai tujuan yang sudah ditetapkan. ${ }^{13}$

Beberapa pendapat tersebut dapat disimpulkan bahwa metode merupakan suatu cara dimana di dalamnya terdapat fungsi sebagai alat untuk mencapai sebuah tujuan. Beberapa tujuan tersebut harus juga dijabarkan secara tepat dan jelas.

Dengan demikian tujuan tersebut banyak membantu merencanakan proses pembelajaran contohnya untuk menentukan alat dan bahan pelajaran, membantu memberi petunjuk untuk memilih metode belajar, dan untuk menentukan mekanisme penelitian. Tujuan semacam itu secara umum lebih memfokuskan pada aspek proses pembelajaran dan bukanlah pada aspek pengajar ataupun aspek kegiatan guru.

Metode pada dunia pendidikan terus dikembangkan agar tujuan pendidikan yang sebenarnya dapat terealisasi, melahirkan output yang siap dalam masyarakat. Metode pembelajaran kemudian dikelompokan menjadi metode klasik dan metode modern. Metode klasik hanya berfokus pada bahan ajar dan proses pembelajaran yang sifatnya satu arah, sistem pengajaran yang lebih familiar dengan sebutan sistem tradisional atau disebut juga sistem monologis.

Proses pembelajaran seperti pondok pesantren (Islamic Boarding School) diidentikan dengan pembelajaran klasik dan tradisional dalam dunia pendidikan di Indonesia dimana proses pembelajaran pendidik mengambil andil penuh dan aktif sedangkan siswa pasif hanya datang, duduk dan mendengarkan. Namun pada pesantren modern saat ini sudah mulai beralih ke metode modern.

Sedangkan metode modern terfokus pada siswa, keaktifan dan kreativitas siswa dituntut ada dalam proses kegiatan pembelajaran, baik itu indoor di dalam kelas maupun outdoor diluar kelas. Sistem seperti ini lah yang mengasah otak anak agar mampu menalar dengan baik untuk menyelesaikan suatu permasalahan-permasalahan yang ada dan mempercepat siswa lebih pintar dan peran pendidik disini adalah hanya sebagai pendamping yang membimbing apabila terjadi kekeliruan atau kesalahan.

${ }^{13}$ Syaiful Bahri Djamarah dan Aswan Zain, Strategi Belajar Mengajar (Jakarta: Rineka Cipta, 1997), h. 53. 
Namun seiring perkembangan ilmu pengetahuan di sekolahsekolah ternama telah menerapkan metode pembelajaran yang sifatnya menyenangkan, edukatif, praktis dan berfokus pada siswa. Pondok Pesantren pun mulai menerapkan metode tersebut. Apabila metode seperti ini dilakukan sejak usia dini dalam hal ini direalisasikan sejak dibangku SD atau MI, maka kedepannya untuk permasalahan-permasalahan yang dihadapinya, siswa akan lebih cepat tanggap dalam menyelesaikannya.

Metode hafalan adalah suatu teknik untuk menghafalkan beberapa kata bahasa Arab (mufradat) atau kalimat-kalimat maupun kaidah-kaidah yang diterapkan oleh seorang pendidik dengan menyerukan peserta didiknya. ${ }^{14}$

Tujuan metode ini adalah melatih daya kognisi, ingatan, dan imajinasi peserta didik agar mampu mengingat pelajaran yang pernah dipelajari dan diketahuinya. Kelebihan dan kekurangan metode menghafal pada proses pembelajaran tentu tidak bisa terelakkan. Namun, kedua hal tersebut dapat diantisipasi sejak awal oleh guru. Jika dilihat dari bentuk dan sifatnya, metode menghafal bisa diklasifikasikan sebagai pekerjaan rumah yang sering disebut sebagai metode resitasi, hal ini sesuai waktu pelaksanaan menghafal ini dimana siswa dapat menghafalkan di luar jam pelajaran di kelas maupun di dalam kelas.

\section{Penguasaan Mufradat}

MacTruck dan Morgan mengatakan "mastery is great skillfulness and knowledge of some subject or activity". 15 Kemampuan seseorang mengaplikasikan pengetahuan yang dimiliki dalam bentuk kegiatan atau aktivitas dapat dikatakan menguasai menurut Mac Truck Dan Morgan. Sehingga kemampuan seseorang dapat diketahui dari bagaimana ia menerapkan pengetahuan yang dimilikinya dengan sebaik-baiknya.

Alat bantu untuk mengetahui kemampuan mufradat /kosa kata pada peserta didik merupakan Instrumen penilaian mufradat itu sendiri. Bentuk-bentuk instrumen tersebut dapat berupa tes. Kosa kata merupakan kata-kata dalam berbagai bentuk yang meliputi: kata-kata lepas dengan atau tanpa imbuhan, dan merupakan kumpulan dari kata-kata yang sama

14 Jalaluddin Rakhmat, Psikologi Komunikasi (Jakarta: Remaja Rosdakarya, 2005), h. 63.

${ }^{15}$ Robert H. MacTruck dan George A. Morgan, Mastery Motivation Conceptualizations and Application (New Jersey: Ablex Publishing Corporation, 1995), h. 283. 
atau berbeda, masing-masing dengan artinya sendiri. Djiwandono menyatakan bahwa "penguasaan mufradat dibagi menjadi dua, yaitu penguasaan kosakata aktif-produktif dan pasif-reseptif". ${ }^{16}$ Penguasaan mufradat bentuk pertama berupa pengetahuan makna kata tanpa diikuti kemampuan untuk menggunakan sendiri atau hanya mengetahui arti kata yang orang gunakan, tanpa disertai kemampuan spontan menggunakan kata tersebut dalam wacananya sendiri. Penguasaan bentuk kedua tidak sekedar memahami arti kata yang didengar atau dibaca, melainkan secara nyata dan mampu memakai kata tersebut dalam wacana untuk mengungkapkan pikirannya.

Penelitian ini merupakan uji dua arah dengan titik signifikansi sebesar $5 \%$ atau 0,05 dengan df n-2 karena menggunakan dua variabel. Untuk melihat tingkat signifikansi permainan kartu kuartet dan metode menghafal terhadap penguasaan mufrodat. Maka, t hitung 4,23 dikonsultasikan dengan tabel $\mathrm{t}$ (pada lampiran) diperoleh $t$ tabel 1, 68595. Sehingga diperoleh $t$ hitung lebih besar dari t tabel maka dapat disimpulkan bahwa permainan kartu kuartet efektif terhadap penguasaan mufrodat siswa.

\section{Simpulan}

Tahapan-tahapan telah dilalui peneliti untuk sampai pada kesimpulan untuk menjawab rumusan-rumusan masalah yang telah dirumuskan, sehingga diperoleh suatu kesimpulan. Penelitian kuantitatif quasi eksperimen, kelas VII A diberikan permainan kartu kuartet sedangkan kelas VII B metode menghafal yang sudah diterapkan oleh guru yang mengajar di Madrasah tersebut. Kelas eksperimen dalam hal ini kelas VII A yang berjumlah 19 siswa setelah dilakukan perlakuan yang kemudian diberikan tes diperoleh 5,8 sebagai nilai rata-rata. Sedangkan VII B sebagai kelas pembanding yang terkontrol dengan jumlah siswa 21 orang setelah dilakukan metode menghafal dengan mufradat yang sama dengan mufradat yang ada dalam kartu kuartet kemudian diberikan tes diperoleh nilai rata-rata 3,6 sehingga dapat disimpulkan bahwa permainan kartu kuartet lebih efektif dibandingkan metode menghafal terhadap penguasaan mufrodat siswa. Sehingga dapat disimpulkan bahwa terjadi signifikansi.

${ }^{16}$ M. Soenardi Djiwandono, Tes Bahasa dalam Pengajaran (Bandung: ITB, 1996), h. 43. 


\section{Daftar Pustaka}

Abdurochman, Abdurochman. "Strategi Pembelajaran Kosakata Bahasa Arab bagi Non Arab." An Nabighoh Jurnal Pendidikan dan

Pembelajaran Bahasa Arab 19, no. 1 (2017): 63.

https://doi.org/10.32332/an-nabighoh.v19i1.758.

Anwar, Khaidir. Beberapa Aspek Sosio-Kultural Masalah Bahasa.

Yogyakarta: Gama Media, 2000.

Arikunto, Suharsimi. Manajemen Penelitian. Jakarta: Rineka Cipta, 2009.

Dianto, Aris. "Uji Independent Sample T-Test Secara Manual." Aksiomatik.

Diakses 10 April 2019.

https://aksiomatik.wordpress.com/2016/09/08/uji-independent-

sample-t-test-secara-manual/.

Djamarah, Syaiful Bahri, dan Aswan Zain. Strategi Belajar Mengajar.

Jakarta: Rineka Cipta, 1997.

Djiwandono, M. Soenardi. Tes Bahasa dalam Pengajaran. Bandung: ITB, 1996.

MacTruck, Robert H., dan George A. Morgan. Mastery Motivation

Conceptualizations and Application. New Jersey: Ablex Publishing

Corporation, 1995.

Rakhmat, Jalaluddin. Psikologi Komunikasi. Jakarta: Remaja Rosdakarya, 2005.

Rapar, J. H. Filsafat Politik Plato. Jakarta: Rajawali Pers, 1996.

Setiyorini, Indah. "Penggunaan Media Permainan Kartu Kuartet Pada Mata

Pelajaran IPS Untuk Peningkatan Hasil Belajar Siswa Di Sekolah

Dasar." Jurnal Penelitian Pendidikan Guru Sekolah Dasar 1, no. 2 (2013): 10.

Tedjasaputra, Mayke S. Bermain, Mainan dan Permainan. Jakarta:

Grasindo, 2001.

Tim Penyusun Kamus Pusat Bahasa. Kamus Besar Bahasa Indonesia. Cet. XVI. Jakarta: Pusat Bahasa, 2008.

Yusuf, A. Muri. Metode Penelitian Kuantitatif, Kualitatif \& Penelitian Gabungan. Jakarta: Kencana, 2014.

Zein, Muhammad. Metodologi Pengajaran Agama. Yogyakarta: AK Group, 1995.

Zubaidillah, Muh Haris, dan Hasan Hasan. "Pengaruh Media Kartu Bergambar (Flash Card) Terhadap Penguasaan Kosakata Bahasa Arab." Al Mi'yar: Jurnal Ilmiah Pembelajaran Bahasa Arab dan Kebahasaaraban 2, no. 1 (2019).

https://doi.org/10.35931/am.v2i1.90. 
238 | Hasnianti 